\title{
Acute Acquired Haemolytic Anaemia Associated with Polyagglutination
}

\author{
K. A. RICKARD, ^ R. J. ROBINSON, and SHEILA M. WORLLEDGE \\ From the Department of Haematology, Royal Postgraduate Medical School, \\ and Nuffield Neonatal Research Unit, Institute of Child Health, Hammersmith Hospital, London W.12
}

Polyagglutination is an abnormality of red cells so that they are aggulutinated by most normal sera, except that from very young infants. Polyagglutination occurs in red cells which have been infected in vitro. Rarely it occurs in vivo, when it has usually been associated with severe bacterial infection. There are very few reported cases where polyagglutinability has led to increased red cell destruction. This report concerns such a case, in which a 14-month-old child developed a severe acute haemolytic anaemia associated with polyagglutination. It is reported because of the rarity of this variety of haemolytic anaemia and because of the intrinsic interest of its mechanism.

\section{Case Report}

The patient, a 14-month-old mongol boy, was admitted in March 1968. He had had no previous illnesses. A chromosome count performed at the age of 6 months showed trisomy 21 . His accomplishments at 14 months were approximately those of a normal 9-month-old child.

Five days before admission he had developed an upper respiratory tract infection associated over the next few days with fever, increasing cough, and breathlessness, and finally cyanosis. On admission he was very ill with severe respiratory distress. His temperature was $40.8^{\circ} \mathrm{C}$., pulse rate $140 /$ minute, respiratory rate $60 /$ minute, and blood pressure $100 / 50 \mathrm{~mm}$. $\mathrm{Hg}$. $\mathrm{He}$ was restless, cyanosed when breathing air, and had intercostal recession. There were rhonchi over the whole chest but no localized signs. Chest $x$-ray showed widespread bilateral consolidation, most marked in the right upper lobe. $\mathrm{Hb} 9.9 \mathrm{~g} . / 100 \mathrm{ml}$., WBC 6000 per cu.mm., with 5340 neutrophils per cu.mm., many of which showed toxic granulation. The other haematological findings on admission and the patient's subsequent progress are shown in the Figure. The culture of a cough swab which was the only culture material obtained before treatment grew no pathogens.

He was nursed in $60 \%$ oxygen which abolished the

Received July 29, 1968.

Present address: St. Elizabeth Hospital, Brighton, Mass., U.S.A. cyanosis, and treated with intramuscular penicillin and ampicillin. The breathlessness was greatly improved within 24 hours, but 3 days after admission he was noticed to be pale and slightly jaundiced and to have developed enlargement of the liver, its edge being palpable $4 \mathrm{~cm}$. below the costal margin. The pallor increased, and 5 days after admission the $\mathrm{Hb}$ level had fallen to $5.6 \mathrm{~g} . / 100 \mathrm{ml}$., with $13 \%$ reticulocytes and 20 nucleated red cells per 100 white cells. Examination of the blood film showed marked polychromasia, some red cell fragments and spherocytes, and the total white cell count had risen to 33,000 per cu.mm. with $79 \%$ neutrophils. Serum bilirubin was $2.5 \mathrm{mg} . / 100 \mathrm{ml}$. (indirect reacting $2.0 \mathrm{mg} . / 100 \mathrm{ml}$.). Schumm's test for methaemalbumin was positive.

A film of bone-marrow from the iliac crest 7 days after admission showed erythroid hyperplasia with megaloblastic features. Leucopoiesis was active with occasional giant metamyelocytes. Megakaryocytes were plentiful and platelet numbers were normal. The myeloid: erythroid ratio was $1 \cdot 5: 1$.

The results of the peripheral blood and bone-marrow aspiration were consistent with an acute haemolytic process. 7 days after admission (28.3.68) $\mathrm{Hb}$ had fallen further to $3.7 \mathrm{~g} . / 100 \mathrm{ml}$. and he was transfused with $120 \mathrm{ml}$. of packed cells which raised his $\mathrm{Hb}$ to $7 \cdot 2$ g. $/ 100 \mathrm{ml}$. Five days later a further transfusion of $190 \mathrm{ml}$. of washed packed red cells raised his $\mathrm{Hb}$ to $9 \cdot 2 \mathrm{~g} . / 100 \mathrm{ml}$. From that time there was no further fall in $\mathrm{Hb}$ level nor evidence of haemolysis.

After the initial improvement his respiratory symptoms were very slow to resolve completely. He still had a respiratory rate of around $\mathbf{4 0}$ per minute and some intercostal recession until 3 weeks after admission. A chest $x$-ray showed that the consolidation was resolving slowly, some change still being apparent in the right upper lobe 5 weeks after admission. Cloxacillin was added to the original antibiotics 7 days after admission and antibiotic treatment was continued for a total of $3 \frac{1}{2}$ weeks. The Mantoux test was repeatedly negative.

Clinical summary. A previously healthy 14month-old mongol child developed a severe bilateral bronchopneumonia. Pathogenic organisms were not isolated. About 1 week after the onset of respiratory symptoms he developed a severe haemolytic anaemia 


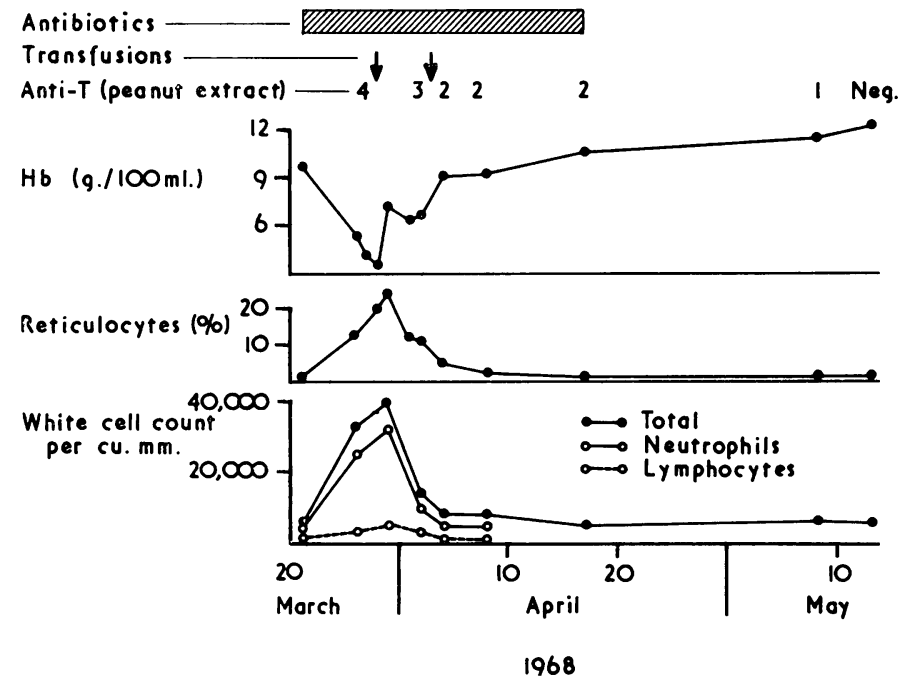

Fig.-Serial haematological and serological data on the patient. Anti-T was a saline extract of peanuts, and ' 4 ' refers to strongly positive agglutination, while ' 1 ' is weakly positive agglutination of the patient's red cells by this extract.

with fall in $\mathrm{Hb}$ from $9.9 \mathrm{~g} . / 100 \mathrm{ml}$. to $3.7 \mathrm{~g} . / 100 \mathrm{ml}$., and required 2 blood transfusions. Haemolysis apparently ceased about 1 week after it started and the pneumonia very slowly resolved. $\mathrm{He}$ is now well.

\section{Haematological Investigations}

These were performed according to the methods of Dacie and Lewis (1963). The Figure shows the changes in the child's haemoglobin, reticulocyte count, total white cell count, and neutrophil and lymphocyte counts.

Further serological and biochemical studies were made to investigate the cause of the haemolysis.

Serological studies. The occurrence of polyagglutination was first noticed during the acute haemolytic episode when grouping and compatibility tests were being done for the first transfusion 7 days after admission. At room temperature a 5\% suspension of the patient's red cells in saline was agglutinated by anti-A, anti-B, and anti-A + B serum as well as by the serum from a group $\mathrm{AB}$ subject, but it was not agglutinated by three cord sera. The agglutination was most marked with fresh sera but all the adult sera used gave some reaction. The cells were also agglutinated to a variable degree by some rabbit antisera, including broad spectrum antihuman globulin serum and antisera to human $\operatorname{IgG}, \operatorname{IgA}, \operatorname{Ig} M$, and the third and fourth components of complement. The degree of agglutination, however, was independent of their content of antibody; in fact the strongest reaction was obtained with an absorbed normal rabbit serum containing no antibodies against human proteins. Finally, the patient's red cells were strongly agglutinated by a saline extract of peanuts (Arachis hypogea) known to contain a specific anti-T-like lectin (Bird, 1964).
Subsequent changes in the agglutinability of the patient's red cells by peanut anti-T are shown in the Figure. Four weeks after the polyagglutination was demonstrated his red cells were no longer agglutinated by the extract. Haemolysis had ceased, $\mathrm{Hb}$ level was slowly rising, and the reticulocyte count was normal (Figure).

The polyagglutination made $\mathrm{ABO}$ and $\mathrm{Rh}$ typing of the patient's cells impossible at room temperature. However, at $37^{\circ} \mathrm{C}$. the polyagglutination was much less marked and the cells were shown to be group $\mathrm{O} R \mathrm{Rh}(\mathrm{D})$ positive. Serum grouping confirmed that the child was group $\mathrm{O}$.

No free antibodies were detected in the patient's serum using enzyme treated red cells and the indirect antiglobulin test. The cold agglutinin titre at the time of maximal haemolysis was normal.

Biochemical studies. During the acute haemolytic episode Schumm's test for methaemalbumin was positive, indicating intravascular haemolysis.

After recovery from the haemolytic episode, further investigations were done to exclude an intrinsic abnormality of the red cells which might have produced haemolysis. The results of these tests were all negative. The osmotic fragility of the red cells was normal both before and after incubation. Autohaemolysis was also normal at 48 hours; $1 \cdot 1 \%$ lysis without added glucose diminished to $0.4 \%$ in the presence of $0.5 \%$ glucose. A screening test (Jacob and Jandl, 1966) for detection of enzyme deficiencies in the pentose phosphate shunt gave a normal result. No Heinz bodies were seen, there was no haemosiderinuria, and Ham's acidified serum lysis test (Ham, 1939) on the patient's cells was negative and a 'cold-antibody haemolysis' test gave a 
normal result. An indirect Donath-Landsteiner test was also negative.

Starch gel electrophoresis of the patient's Hb showed $\mathrm{Hb} / \mathrm{A}$ and $\mathrm{Hb} / \mathrm{A}_{2}$ in normal amounts. A sickle-cell preparation was negative. Alkali denaturation by the Singer technique (Singer, Chernoff, and Singer, 1951) showed only $2 \cdot 7 \%$ of $\mathrm{Hb} / \mathrm{F}$.

Full blood counts, osmotic fragilities, and autohaemolysis and screening tests for enzyme deficiencies were performed on the patient's parents, both maternal grandparents, and paternal grandfather. The results were normal.

No intrinsic red cell abnormality could be demonstrated in the patient's red cells nor in those of his parents and grandparents, and thus an hereditary red cell defect as a cause for the haemolytic anaemia is unlikely.

\section{Discussion}

Polyagglutination of red blood cells sometimes occurs in vitro and very rarely occurs in vivo. In vitro polyagglutination is known as the HübenerThomsen-Friedenreich phenomenon, and it is believed to be due to bacterial contamination (Friedenreich, 1930). Bacterial enzymes are thought to uncover a red cell antigen, called the ' $T$ ' antigen which is capable of reacting with anti- $T$ agglutinins present in most normal sera except cord sera. Rabbit sera may also contain anti- $T$ and the direct antiglobulin test on polyagglutinable cells may be thought to be positive if control normal rabbit sera are not included.

Polyagglutination occurring in vivo has been seen on rare occasions associated with severe systemic bacterial infection (Levine and Katzin, 1938; Gaffney and Sachs, 1943; Basil-Jones, Sanger, and Walsh, 1946; Boorman, Loutit, and Steabben, 1946; Engleson and Grubb, 1949; Höllander, 1951; Reepmaker, 1952; de Muralt, Hässig, and de Reynier, 1952). Again, the polyagglutination has been thought to be due to uncovering of $T$ antigen by bacterial enzymes. However, the phenomenon has only seldom been reported as being accompanied by increased red cell destruction (Dacie, 1962). We have found only 9 such cases. Gasser and Höllander (1951) described a 7-week-old child with acquired haemolytic anaemia associated with this phenomenon, and van Loghem, van der Hart, and Land (1955) described a severe haemolytic transfusion reaction in a child who had polyagglutinable red cells. Dausset, Moullec, and Bernard (1959) described a case of chronic acquired haemolytic anaemia associated with polyagglutinability due to a ' $T$, antigen on red cells which they showed was similar but not identical to the $T$ antigen described above. van Loghem (1965) reviewed 6 further cases of haemolytic anaemia with red cell polyagglutinability.
The present case has been reported because it is thought the haemolytic anaemia and the polyagglutinability were causally related. The evidence for this rests first on the concurrence of the two phenomena, and secondly on the absence of any other demonstrable cause for the haemolysis. The Figure shows that the agglutination by anti-T was most marked when the haemolysis was at its height, and further that haemolysis ceased as this agglutination disappeared. When the child had recovered, his red cells showed no intrinsic defect in morphology, fragility, enzyme content, or $\mathrm{Hb}$ content. Nor was there any evidence of abnormal antibodies in the patient's serum at the time of the acute haemolytic episode or subsequently.

The cause of the polyagglutination was not shown, but it seems reasonable to ascribe it to the respiratory illness for which the child was admitted. No pathogenic organisms were isolated, but the neutrophil leucocytosis and the toxic granulation of the neutrophils strongly suggest a bacterial infection.

The relation, if any, between mongolism and polyagglutinability obviously cannot be assessed on the basis of a single case. None of the other reported cases of polyagglutinability were mongols. We have no evidence that this mongol child had a red cell enzyme deficiency, but Baikie et al. (1965) reported an increase in phosphohexokinase activity of erythrocytes in mongolism. Their work has subsequently been confirmed by Burtels, Kruse, and Tolksdorf (1968). Rosner et al. (1965) have reported increases in the erythrocyte content of galactose-1-phosphate uridyl transferase and of glucose-6-phosphate dehydrogenase in trisomic mongolism. However, there is no evidence that these enzymic changes predispose to haemolysis in mongolism (A. G. Baikie, 1968, personal communication).

\section{Summary}

A 14-month-old mongol child developed acute haemolytic anaemia during the course of severe bronchopneumonia. The haemolysis was associated with polyagglutinability of the patient's red cells. Since no other cause for the haemolytic anaemia was shown, it was considered to be due to the polyagglutination. As the child recovered from the chest infection the polyagglutinability disappeared and the haemolysis subsided. $\mathrm{He}$ is now clinically well and haematologically normal.

We thank Professor J. V. Dacie for his help in the preparation of this report, and Mrs. L. Perks for drawing the figure. 
REFERENCES

Baikie: A. G., Loder, P. B., de Gruchy, G. C., and Pitt, D. B. (1965). Phosphohexokinase activity of erythrocytes in mongolism. Another possible marker for chromosome 21. Lancet, 1, 412.

Basil-Jones, B., Sanger, R. A., and Walsh, R. J. (1946). An agglutinable factor in red blood cells. Nature (Lond.), 157, 802.

Bird, G. W. (1964). Anti-T in peanuts. Vox Sang. (Basel), 9, 748.

Boorman, K. E., Loutit, J. F., and Steabben, D. B. (1946). Polyagglutinable red cells. Nature (Lond.), 158, 446.

Burtels, H., Kruse, K., and Tolksdorf, M. (1968). Enzymes in Down's syndrome. Lancet, 1, 820.

Dacie, J. V. (1962). The Haemolytic Anaemias: Congenital and Acquired. Part II. The Auto-immune Haemolytic Anaemias, 2nd ed., p. 588 . Churchill, London.

- and Lewis, S. M. (1963). Practical Haematology, 3rd ed. Churchill, London.

Dausset, J., Moullec, J., and Bernard, J. (1959). Acquired hemolytic anemia with polyagglutinability of red blood cells due to a new factor present in normal human serum (Anti $T_{n}$ ). Blood, 14, 1079.

Engleson, G., and Grubb, R. (1949). Abnormal agglutinability of red cells in pyogenic infections. Amer. F. clin. Path., 19, 782.

Friedenreich, V. (1930). The Thomsen Haemagglutination Phenomenon. Levin and Munksgaard, Copenhagen.

Gaffney, J. C., and Sachs, H. (1943). Polyagglutinability of human red blood cells. F. Path. Bact., 55, 489.

Gasser, C., and Höllander, L. (1951). Anémie hémolytique acquise aiguë provoquée par des auto-anticorps, accompagnée de purpura thrombocytopénique, chez un nourrisson de 7 semaines. Rev. Hémat., 6, 316.
Ham, T. H. (1939). Studies on destruction of red blood cells. I. Chronic hemolytic anemia with paroxysmal nocturnal hemoglobinuria: an investigation of the mechanism of hemolysis, with observations on five cases. Arch. intern. Med., 64, 1271.

Höllander, L. (1951). Polyagglutinabilitäts der Erythrocyten bei einer. Pneumokokkenmeningitis. Helv. paediat. Acta 6, 149.

Jacob, H. S., and Jandl, J. H. (1966). A simple visual screening test for glucose-6-phosphate dehydrogenase deficiency employing ascorbate and cyanide. New Engl. F. Med., 274, 1162.

Levine, P., and Katzin, E. M. (1938). Temporary agglutinability of red blood cells. Proc. Soc. exp. Biol. (N.Y.), 39, 167.

van Loghem, J. J. (1965). Some comments on autoantibody induced red cell destruction. Ann. N.Y. Acad. Sci., 124, 465.

ability of red cells as a cause of severe haemolytic transfusion reaction. Vox Sang. (Basel), 5, 125.

de Muralt, G., Hässig, R., and de Reynier, H. (1952). Un cas de polyagglutinabilité transitoire des érythrocytes chez une patiente du groupe A. Rev. Hémat., 7, 372.

Reepmaker, J. (1952). The relation between polyagglutinability of erythrocytes in vivo and the Hübener-Thomsen-Friedenreich phenomenon. F. clin. Path., 5, 266.

Rosner, F., Ong, B. H., Paine, R. S., and Mahanand, D. (1965). Biochemical differentiation of trisomic Down's syndrome (mongolism) from that due to translocation. New Engl. $\mathcal{F}$. Med., 273, 1356.

Singer, K., Chernoff, A. I., and Singer, L. (1951), Studies on abnormal hemoglobins. I. Their demonstration in sickle cell anemia and other hematologic disorders by means of alkali denaturation. Blood, 6, 413. 